\title{
Japanese Encephalitis as an Emerging Virus: The Emergence and Spread of Japanese Encephalitis Virus in Australasia
}

\author{
J.S. Mackenzie, C.A. Johansen, S.A. Ritchie, A.F. van den Hurk, \\ and R.A. HALL
}

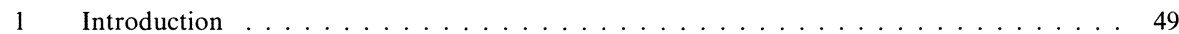

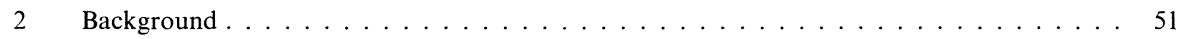

$2.1 \mathrm{JE}$ and Other Flaviviruses of Indonesia . . . . . . . . . . . . . . . . . . 51

2.1.1 The Western Indonesian Archipelago (Sumatra, Java, Kalimantan, Bali) . . . . . . . . . 51

2.1.2 The Eastern Indonesian Archipelago (Wallacea) . . . . . . . . . . . . . . . . . . 52

$2.2 \mathrm{JE}$ and Other Flaviviruses of Australasia . . . . . . . . . . . . . . . . . . . . . 53

2.2.1 Flaviviruses of Papua New Guinea and Irian Jaya . . . . . . . . . . . . . . . . . . . . . . . . . . . . . . . . . . . . .

2.2 .2 Flaviviruses of Australia . . . . . . . . . . . . . . . . . . . . . . . . . 54

3 The Emergence of JE in Australasia . . . . . . . . . . . . . . . . . . . 55

3.1 The Emergence of JE Virus in the Torres Strait of Northern Australia . . . . . . . . . . 55

3.2 JE Virus in Papua New Guinea and Irian Jaya . . . . . . . . . . . . . . . . . . . 58

4 Vectors and Vertebrate Hosts: The Potential for Establishment in Australasia . . . . . . . 59

4.1 Entomological Studies: JE Vectors in Australasia . . . . . . . . . . . . . . . . . . . . . . . . . . . 60

4.2 Vertebrate Hosts of JE and JE Serogroup Viruses in Australasia . . . . . . . . . . . . . . 61

5 Possible Mechanisms of Spread of JE into and within Australasia . . . . . . . . . . . . 64

6 The Potential of JE to Spread into the Pacific . . . . . . . . . . . . . . . . . 67

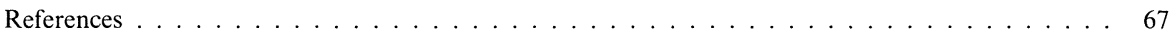

\section{Introduction}

Japanese encephalitis (JE) virus has a great propensity to spread, expanding its range through much of southeastern Asia in the past four decades (UMENAI et al. 1985; Burke and Leake 1988; Vaughn and Hoke 1992; Monath and Heinz 1996). In the 1990s, JE spread into southern Pakistan (IgARAsHi et al. 1994) and to Haryana State (Prasad et al. 1993) and Kerala State (DHANDA et al. 1997) in northwestern and southwestern India, respectively. In the east, JE has invaded the eastern Indonesian archipelago, New Guinea, and the Torres Strait of northern Australia (HANNA et al. 1996b; MACKEnZIE et al. 1997a). The eastward spread of

Department of Microbiology and Parasitology, The University of Queensland, Brisbane, Queensland 4072, Australia

Tropical Public Health Unit, Queensland Health, PO Box 1103, Cairns, Queensland 4870, Australia 
JE from the Oriental to the Australasian zoogeographic region and the threat this poses to the Pacific is the focus of this chapter. It is also interesting to note that there are also certain parallels in the emergence of JE in the Australasian region with the recent emergence of West Nile (WN) virus in North America, and particularly the emergence of the two viruses in novel zoogeographic regions.

Until recently, Wallace's Line, a hypothetical line separating the Oriental from the Australasian zoogeographic region, was thought to be the southeastern limit of JE virus (Kanamitsu et al. 1979; Marshall 1988; Mackenzie et al. 1997a). Wallace's Line passes between Bali and Lombok islands, north through the Strait of Makasar between Kalimantan and Sulawesi (Fig. 1). A second hypothetical line, Weber's Line (Fig. 1), also purports to delineate zoogeographic boundaries but is set further east, extending between Timor and northwest Australia and then north through the Moluccan Sea east of Sulawesi (Kanamitsu et al. 1979; Mackenzie et al. 1997a). The area between Wallace's Line and Weber's Line is referred to as Wallacea, east of which lies Australasia, encompassing Irian Jaya, Papua New Guinea, and Australia. It has been clearly established that JE virus is the major encephalitic flavivirus to the north and west of Wallacea, whereas Murray Valley encephalitis (MVE) virus is the major encephalitic flavivirus of Australasia (Marshall 1988). However, it is difficult to determine the incidence and distribution of the two viruses in Wallacea using serological techniques as there are a number of other flaviviruses circulating in this area, and sequential exposure to one or more results in complex patterns of serological cross-reactions. These other viruses are discussed below.

In this chapter, we describe the mosquito-borne flaviviruses found in Indonesia on either side of Wallace's Line, and in New Guinea and Australia. There is a strong reason for geographical descriptions of flaviviruses: not only is it unusual to have so many related viruses circulating and possibly competing for vectors and vertebrate hosts, but it also emphasises the problems inherent in serological studies due to heterotypic antibodies following multiple exposures. These problems are

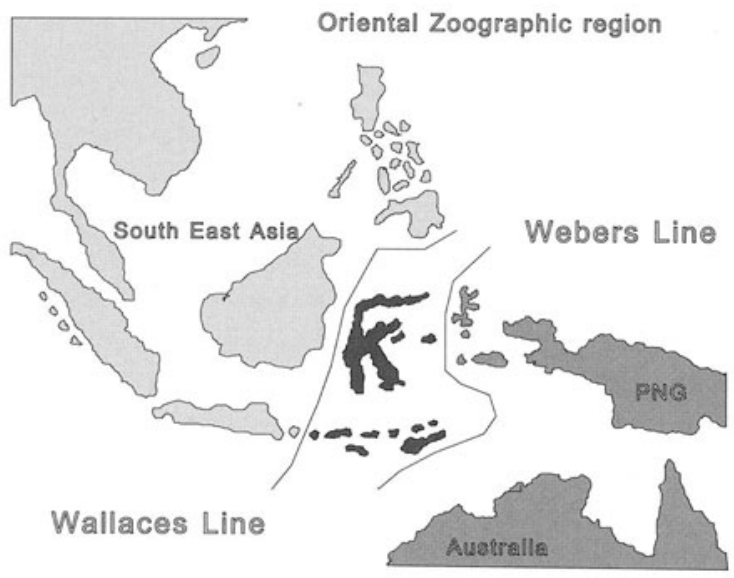

Australasian Zoographic region
Fig. 1. The Oriental and Australasian zoogeographic regions: the position of the Wallace and Weber lines, and the concept of Wallacea. (From MACKENZIE et al. 1997 with permission) 
perhaps more accentuated in this area of the world than anywhere else. However, because of their ubiquity in Indonesia and coastal New Guinea, the dengue viruses will not be discussed further, although these viruses remain significant causes of disease and contribute to the high incidence of heterotypic flaviviral antibodies. The emergence of JE virus in the Torres Strait of northern Australia will then be described, with studies carried out in Papua New Guinea (PNG) and Irian Jaya. The final sections will discuss possible vectors and vertebrate hosts in Australasia with respect to the potential for the virus to become established, and the possible modes of spread of JE both to and within the Australasian region. A short concluding section will address the potential for JE to spread further within the Pacific.

\section{Background}

\subsection{JE and Other Flaviviruses of Indonesia}

\subsubsection{The Western Indonesian Archipelago (Sumatra, Java, Kalimantan, Bali)}

Seroepidemiological surveys indicated that JE was present in various parts of Indonesia in the 1960s (HotTA et al. 1970a,b), with the first reported clinical illness in 1971 in Jakarta (L.K. KHo, cited by VAN PEenen et al. 1975b; Wuryad and Soroso 1989). Initial virus isolations were made in pig-raising areas near Jakarta, implicating Culex tritaeniorhynchus as the major vector (ATMOSOEDJONO et al. 1973) and pigs as the amplifying hosts (VAN PEenen et al. 1974a,b). VAN PeEnen et al (1975b) isolated JE from Cx. tritaeniorhynchus, Cx. gelidus, and sentinel pigs in Kapuk, Jakarta. JE virus was subsequently isolated from $C x$. tritaeniorhynchus, $C x$. gelidus and Cx. fuscocephala mosquitoes in a pig-breeding area near Bogor, West Java (VAN PeEnen et al. 1975a). These studies suggested that there was a correlation of C.x. tritaeniorhynchus breeding with agricultural practices rather than with rainfall (VAN PEENEN et al. 1975b). Further studies carried out at Kapuk demonstrated a close dependence of JE viral activity on the population dynamics of Cx. tritaeniorhynchus (OLSON et al. 1985b). More than 20 isolates of JE were obtained from mosquitoes during this latter study, most of which were from $C x$. tritaeniorhynchus with a few isolates from Cx. gelidus, C.x. vishnui, and Cx. fuscocephala. In Central Java where pigs are less common, JE virus was isolated from seven species of mosquitoes trapped in cattle shelters, suggesting that cattle may be involved in some natural transmission cycles in Indonesia (TAN et al. 1993). Antibodies to JE virus have been reported in horses (WIDJAJA et al. 1995) and cattle (TAN et al. 1993) in Java.

A prospective study carried out in 1990-1992 in Bali found that 19 of 47 children hospitalised with encephalitis were serologically confirmed as being infected with JE (T. Soroso, S. Ganefa, B. Widarso, personal communication). Further studies in Bali of another 77 suspected cases found that 44 had JE 
antibodies in their cerebrospinal fluid (CSF) by ELISA (T. Soroso, S. Ganefa, B. Widarso, personal communication). In addition, there have been reports of tourists from Bali being infected with JE (MACDONALD et al. 1989; WiTtesJo et al. 1995; BuHL et al. 1996). Serologically confirmed cases of JE on Bali were recently reported by YoshidA and colleagues (1999). The crude annual incidence rate of JE disease in southern Bali is about 3.1 cases per 100,000 children aged below 14 years, and cases occurred throughout the year (T. Soroso, S. Ganefa, B. Widarso, personal communication). JE virus has been isolated from mosquitoes in Bali (R. Graham, personal communication), and several known JE vector species have been found in significant numbers, including $C x$. tritaeniorhynchus, Cx. fuscocephala, Cx. gelidus, and Cx. vishnui (LEE et al. 1983). Neutralising antibodies to JE virus were found in $48 \%$ of pigs in Bali, and in a number of other species of livestock (T. Soroso, S. Ganefa, B. Widarso, personal communication).

Other than the four dengue viruses, several other flaviviruses have either been isolated or implicated in disease on serological grounds in western Indonesia or contiguous areas of eastern Malaysia. They include Zika virus, which was implicated as a cause of fever in patients in central Java (OLSON et al. 1981); Tembusu virus, which was isolated in Sarawak (PlATt et al. 1975); and WN virus, which had also been isolated in Sarawak (Karabatsos 1985). Furthermore, the Australasian Kunjin (KUN) virus, which has recently been reclassified as a subtype of WN virus, has also been isolated from Cx. pseudovishnui mosquitoes in Sarawak (BoweN et al. 1970)

\subsubsection{The Eastern Indonesian Archipelago (Wallacea)}

The eastern Indonesian archipelago includes Nusa Tenggara Barat or West Nusa Tenggara (Lombok, Sumbawa), Nusa Tenggara Timur or East Nusa Tenggara (Flores, Sumba, Timor, Komodo), and Sulawesi (Celebes). This part of Indonesia notionally comprises 'Wallacea'. Irian Jaya, although part of Indonesia, will be discussed separately under New Guinea as it falls geographically within the Australasian zoogeographic region. As noted above, seroepidemiological studies in Wallacea have been difficult to interpret because of heterotypic responses. The flaviviruses believed to be present include JE virus; the Australasian members of the JE serological complex, MVE, KUN, and Alfuy (ALF) viruses; Kokobera (KOK) and Stratford (STR) viruses, two Australasian viruses which were previously classified as members of the JE serological group, but have now been placed in a separate group of their own; Edge Hill (EH) and Sepik viruses, two Australasian viruses of the Yellow fever virus group; and Dengue virus types $1-4$ (Karabatsos 1985; MACKenZIE et al. 1994; HeINZ et al. 2000). In addition, there is serological evidence that Zika and Tembusu viruses may be present (OLson et al. 1983).

Early seroepidemiological studies were carried out by НоттA and colleagues (1967, 1970a) in Lombok using haemagglutination inhibition (HI) and a restricted number of antigens, but the results were inconclusive. Subsequently KanAMITSU and colleagues (1979) reported neutralising antibodies to JE virus in human sera collected at various locations in Wallacea (and at Jayapura, Irian Jaya, in the 
Australasian zoogeographic region). While most sera were multi-reactors, reanalysis based on the virus eliciting the only or highest titre, suggested a low incidence of JE positive sera only in Lombok. Most of the multi-reactor sera were shown to have highest titres to dengue 2 virus. The authors also suggested that, as the age pattern of the JE antibody-positive sera in Lombok differed from that in endemic areas of $\mathrm{JE}$, and as a significant proportion of the residents of Lombok are Hindu, it may be that much of the JE antibody-positive human sera in Lombok was acquired through infection in Bali, a holy place for Hindus. OLsON et al. (1983) found $\mathrm{HI}$ and neutralising antibody to JE virus in humans and animals and in horse and cows, respectively, in Lombok. Furthermore, neutralising antibodies to dengue 2, Zika, Tembusu, KUN, and Sepik viruses were found in human sera and to Sepik, MVE and KUN viruses in domestic animals (OLSON et al. 1983), again demonstrating the problems inherent in seroepidemiological studies when a number of different flaviviruses are enzootic. JE virus was isolated from Cx. tritaeniorhynchus, Anopheles vagus, and An. annularis mosquitoes in Lombok in 1978-1979 (OLSON et al. 1985a) and from Cx. tritaeniorhynchus in Flores Island in 1981 (J.G. Olson, unpublished results). This latter isolate is the most easterly isolation of JE virus prior to the 1995 outbreak on Badu, 2,200km to the east. HI antibodies to JE were also found in pigs in Timor (P. Daniels, I. Sandow, personal communication), and in human and animal sera collected from 1993 to 1997 in Sulawesi, East Nusa Tenggara and West Nusa Tenggara (T. Soroso, S. Ganefa, B. Widarso, personal communication), but the lack of specificity of the test renders the results questionable.

\subsection{JE and Other Flaviviruses of Australasia}

\subsubsection{Flaviviruses of Papua New Guinea and Irian Jaya}

MVE virus is recognised as the major encephalogenic flavivirus of the Australasian region, and occurs in both PNG and Irian Jaya. Two cases of encephalitis caused by MVE have been reported from southern Papua New Guinea (FrENCH et al. 1957) and Irian Jaya (Essed and VAN ToNGERAN 1965) in 1956 and 1960 respectively. MVE virus was also isolated from mosquitoes trapped at Maprik in East Sepik Province of PNG (MARshall 1988). The human and the mosquito isolates were shown to be genetically distinct from each other and from Australian MVE isolates (Lobigs et al. 1986, 1988; Coelen and MACKenzie 1988; Coelen et al. 1989; Mackenzie et al. 1996b). Two additional isolates were obtained from $C x$. sitiens subgroup mosquitoes trapped at Balimo in the Aramia River area of Western Province in 1998 (JoHANSEN et al. 2000). Early seroepidemiological studies carried out in 1956-1957 demonstrated that neutralising antibodies to MVE virus were widespread in various parts of PNG, except in the highlands (ANDERSON et al. 1960). Most sera showed cross-reactions with JE virus, and indeed some sera collected in the Aramia River area of Western Province exhibited higher titres to JE than to MVE virus. Although the authors suggested that these latter results were 
probably due to heterologous antibodies resulting from sequential infections with other flaviviruses, the presence of JE virus in southern PNG at that time cannot be ruled out. Indeed the authors commented that the Aramia River area was the most heavily and consistently infected region of PNG. Antibodies to MVE related viruses were also found in a variety of waterbirds in PNG, including the Little black cormorant, Plumed egret, Snakebird, Nankeen night heron, Mangrove heron, and Pied goose (ANDERSON et al. 1960). A high incidence of flavivirus antibodies with evidence of heterologous responses was also reported in the 1960s for coastal lowlands (Wisseman et al. 1964) and in East Sepik Province (R.A. Hawkes, unpublished results cited by MARSHALL 1988), but no flavivirus antibodies were detected in sera from the PNG highlands. HAwkES was able to determine that MVE virus transmission was frequent in the Sepik area, and that continuous transmission of both KUN and KOK viruses occurred throughout the year (R.A. Hawkes, unpublished results cited by MARSHALL 1988). KOK virus was also isolated from mosquitoes in the Sepik area (Marshall 1988). Neutralising antibodies to MVE were also observed in three adult sera collected from near Sentani Lake in the north of Irian Jaya (VAN Tongeren et al. 1960), in domestic chickens and cattle in PNG (DohERTy et al. 1973), and in human and avian sera collected in East Sepik Province between 1990 and 1993 (R. Sanders, unpublished results; A.K. Broom, J.S. Mackenzie, unpublished results). Neutralising antibodies to KUN virus were detected in a serum specimen from Jayapura in Irian Jaya (KANAMITSU et al. 1979).

Sepik virus, now classified as a member of the Yellow fever virus group (HeINZ et al. 2000), was first isolated from Mansonia septempunctata, Ficalbia flavens, Ficalbia spp., and Armigeres spp. trapped in the Sepik district of Papua New Guinea (Woodroofe and Marshall 1971; Karabatsos 1985). It has been implicated in human febrile disease (Woodroofe and Marshall 1971). An isolate of Sepik virus was also obtained from a pool of C.x. sitiens subgroup mosquitoes trapped at Balimo in Western Province in 1998 (JoHANSEN et al. 2000).

\subsubsection{Flaviviruses of Australia}

As mentioned above, MVE virus is the major encephalogenic flavivirus in Australia, and one of three JE serological group viruses found in Australia, the other two being KUN and ALF viruses. It is enzootic across most of northern Australia. although fewer human cases have been reported in the northeast of the continent. The ecology and geographic range of MVE virus have been reviewed elsewhere (Marshall 1988; Mackenzie et al. 1994, 1996b; SPencer et al. 2001). Briefly, however, the natural cycle of MVE is believed to be between Cx. annulirostris mosquitoes and various ardeid waterbirds, particularly the Nankeen night heron (Nycticorax caledonicus), although other mosquito species (RuSsELL 1995) and vertebrate hosts may also be involved. Clinically, the disease is similar to other flaviviral encephalitides, with an approximate infectivity to case ratio of 1,000:1. About $20 \%$ of clinical cases are fatal, and about $40 \%$ of those who recover have permanent neurological sequelae (BennetT 1976; Mackenzie et al. 1993; Cordova et al. 2000). Of the other JE serological group viruses in Australia, only KUN has 
been associated with human disease. While it occasionally causes mild encephalitis (MACKENZIE et al. 1993; see chapter by Hall et al., this volume), it is more often associated with a febrile illness and, in some cases, with rash and/or myalgia (see chapter by Hall et al., this volume). The ecology of KUN virus in Australia is similar to that of MVE virus, with the same vectors and vertebrate hosts, but with a slightly extended geographic range (MARshall 1988; MACKENZIE et al. 1994; see chapter by Hall et al., this volume). ALF virus is closely related to MVE and indeed has recently been reclassified as a subtype of MVE (HEINZ et al. 2000), although there is reason to believe that this may have been premature. It has not been associated with human disease. ALF virus, like MVE and KUN viruses, appears to have a natural cycle between culicine mosquitoes and waterbirds (MACKENZIE et al. 1994).

KOK and STR viruses, formerly classified in the JE serogroup, have now been elevated into a small serogroup of their own (HEINZ et al. 2000). KOK virus has been associated with polyarticular disease, but STR virus has been associated with only subclinical human infections on serological grounds (reviewed by MACKENZIE et al. 1994). Both viruses are believed to have a natural cycle involving mosquitoes and marsupials. EH virus, a member of the Yellow fever virus group, also has a natural cycle involving mosquito vectors and marsupials (MACKENZIE et al. 1994). From seroepidemiological studies, it appears that occasional human infections with EH virus occur (HAwkEs et al. 1985), and there has been one unconfirmed report implicating EH virus as the possible etiological agent in a patient presenting with arthralgia, myalgia, and fatigue (AAskov et al. 1993). Finally, while dengue viruses are not endemic in Australia, regular importations by returning travellers and tourists into north Queensland areas populated with the vector, Ae. aegypti, cause occasional outbreaks (MACKENZIE et al. 1996a; HANNA et al. 2001).

\section{The Emergence of $\mathbf{J E}$ in Australasia}

\subsection{The Emergence of JE Virus in the Torres Strait of Northern Australia}

Three cases of encephalitis, two of them fatal, were reported from Badu, an island in the central Torres Strait (Fig. 2) of northern Australia in March/April 1995. Initially thought to be MVE virus, tests carried out by Queensland Health Scientific Services in Brisbane, and at the Armed Forces Research Institute of Medical Sciences in Bangkok, confirmed that the infections were due to JE virus (HANNA et al. 1996b). This was most unexpected as the nearest focus of JE virus activity was in Bali, while the nearest isolate of JE had been from Flores Island, approximately 3,000 and $2,200 \mathrm{~km}$ west of the Torres Strait, respectively. Subsequent investigations revealed that 55 people on four islands in the central and northern Torres Strait had serological evidence of subclinical infection with JE virus, and 90 pigs on nine 


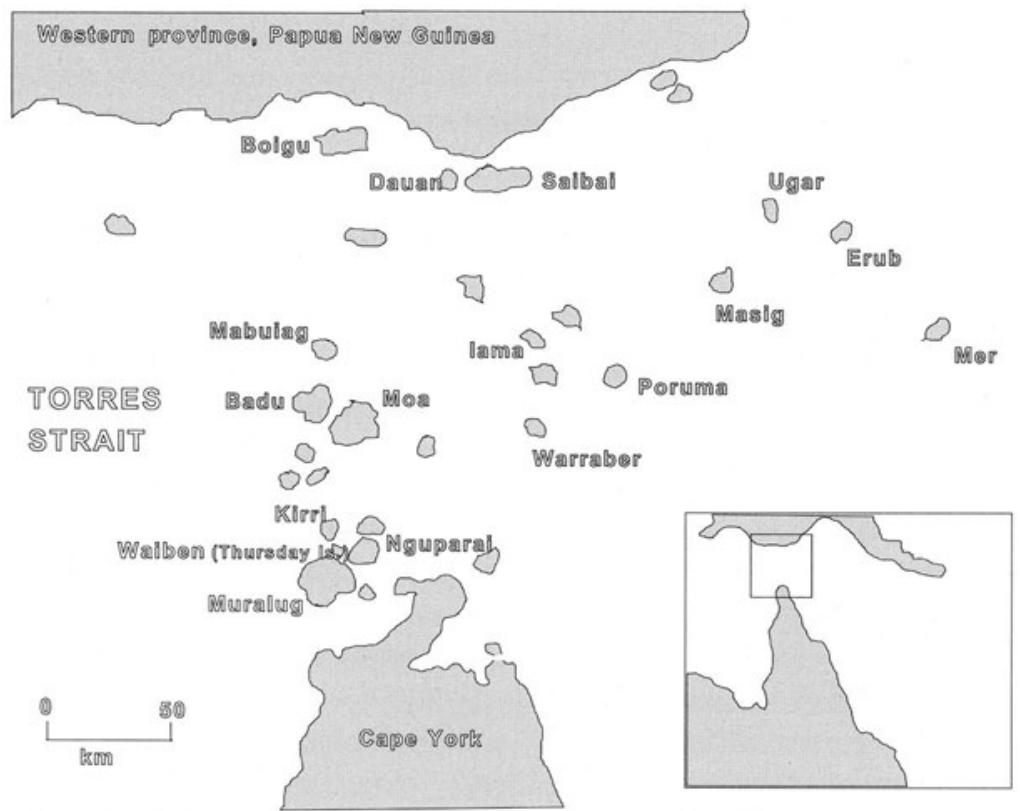

Fig. 2. The islands of the Torres Strait of northern Australia. (From MACKEnziE et al. 1997 with permission)

islands had seroconverted to JE virus. A total of ten virus isolations were obtained, two from subclinical human infections and eight from $C x$. annulirostris mosquitoes (HANNA et al. 1996b; RitchiE et al. 1997). These studies clearly demonstrated that the large number of domestic pigs and the prolific $C x$. annulirostris breeding sites in close proximity to human habitation drove the outbreak (HANNA et al. 1996b).

Inactivated $\mathrm{JE}$ vaccine was offered to all of the residents of the outer Torres Strait islands in December 1995-January 1996, and about 88\% of the residents received at least two doses (HANNA et al. 1996a). In addition, a surveillance system was established to monitor for further incursions using young seronegative sentinel pigs (SHIELD et al. 1996). The success of both programmes was evident when pigs on Saibai Island seroconverted to JE virus in 1996 (SHIELD et al. 1996) and 1997 (J. Lee and D. Phillips, personal communication), without any further human cases.

A further incursion of JE occurred in the Torres Strait in 1998, with a case in an unvaccinated child from Badu, and with pig seroconversions extending from the northern islands south to the Cape York Peninsula. On Badu, 45 isolations of JE virus were obtained, one from a pig and 44 from mosquito pools (43 pools of $C x$. annulirostris and one pool of Ochlerotatus vigilax). This was clearly the most widespread outbreak in the Torres Strait to date. Concurrently, a fisherman contracted the infection near the mouth of the Mitchell River in southwest Cape York, the first human case on mainland Australia (HANNA et al. 1999). Serological surveys showed no evidence of other human infections in nearby communities, but 
young pigs at a nearby property were shown to have antibodies to JE virus. Further north in the Northern Peninsular area of Cape York, domestic pigs at several communities near Bamaga seroconverted to JE virus, and two isolations of JE virus were made from the pig sera, but there was no serological evidence of any human infections in the communities. No isolates of JE virus were obtained from mosquitoes trapped at both Cape York areas (VAN DEN HURK et al. 2001a). Further JE virus activity occurred again in the Torres Strait in 2000 and 2001. In 2000, sentinel pigs seroconverted on Moa and Badu, and virus isolations were made from three sentinel pigs and from a pool of $C x$. gelidus mosquitoes on Badu (MACKENZIE et al. 2001; Pyke et al. 2001; yAN DEN HuRK et al. 2001b), and from Cx. sitiens subgroup mosquitoes on Saibai. There were no human cases on Badu, probably due to the widespread use of inactivated JE vaccine in the central and northern Torres Strait, but this may also have been associated with the relocation of the domestic pig population from back yards to a communal piggery about $3 \mathrm{~km}$ from the community. Seroconversions in sentinel pigs were again observed in early 2001 on Badu and Moa (G.A. Smith, P.W. Daniels, J. Lee, personal communication). Thus there has been evidence of JE virus incursions into the Torres Strait every year between 1995 and 2001, except for 1999 (Fig. 1).

Molecular epidemiological studies were undertaken on the JE virus isolates obtained in an attempt to determine the origins of the viruses causing the outbreaks. Nucleotide sequence analyses of the genomes of the ten 1995 isolates showed that they were closely related to each other with greater than $99 \%$ homology, indicating that the 1995 outbreak originated from a single focus of virus activity (Hanna et al. 1996b; Ritchie et al. 1997; Mackenzie et al. 1997a). A comparison of the nucleotide sequences in the prM and E gene of the 1995 and 1998 isolates with other JE viruses (HANNA et al. 1996b; RitchiE et al. 1997; HANNA et al. 1999; M. Poidinger and J.S. Mackenzie, unpublished results) showed that they were related to genotype 2 viruses, as defined by CHEN et al. (1990, 1992), and most similar to 1981 isolates from Java, but also relatively close to a 1970 isolate from Kuala Lumpur, and a 1983 isolate from southern Thailand. However, although similar, the Javanese isolates displayed at least 5\% divergence, indicating that they were still relatively distant. A more detailed study using one of the human isolates, FU strain, further confirmed and extended these earlier observations, and provided the complete nucleotide sequence of this strain (WiLliams et al. 2000). Thus, although these results showed clearly that the 1995 Torres Strait outbreak originated from a single focus of virus activity, and that the viruses causing the 1995 and 1998 outbreaks belonged to the southeast Asian genotype, they did not give any indication of the source of the outbreak. However, sequence studies in the NS5$3^{\prime}$ UTR of the Badu isolates demonstrated an 11-base deletion in the genome immediately downstream from the stop codon of the open reading frame (PoIDINGER et al. 1996), which could provide an important 'finger-print' for future studies. However, the viruses isolated from pigs and mosquitoes in 2000 were genetically different from those isolated in 1995 and 1998, and were found to belong to genotype 1 (PYKE et al. 2001), a genotype more commonly associated with isolates 
from Cambodia and northern Thailand (CHEN et al. 1990, 1992), yet they still maintained the 11-base deletion in the $3^{\prime}$ UTR (PYKE et al. 2001).

\subsection{JE Virus in Papua New Guinea and Irian Jaya}

The most probable geographic source of JE virus incursions into the Torres Strait was southern PNG or Irian Jaya. The northern Torres Strait islands (Saibai, Boigu, Dauan) are only a few kilometres from the coast of Western Province, PNG. JE may have therefore been introduced into the Torres Strait via wind-blown infected mosquitoes or by infected birds. However, if JE had become established in Western Province, PNG, it may not have been recognised; medical facilities are few in number, and those that are available do not have facilities for viral diagnosis. Thus cases of viral encephalitis in Western Province would probably have been diagnosed as cerebral malaria.

Seroepidemiological studies of JE in human and porcine sera collected in PNG were undertaken to determine the presence and prevalence of JE in PNG. In 19951996, pig sera were collected from different localities throughout Western Province and about $50 \%$ were found to have neutralising antibodies to JE virus (J. Shield and R. Lunt, unpublished results). Over 3,000 human sera collected between 1989 and 1998 from different localities in Western, Gulf and Southern Highlands Provinces were screened for antibodies to JE and the related flaviviruses. Although interpretation of serological results is difficult because of heterotypic responses, the results clearly suggested that antibodies to JE virus were present in about $22 \%$ of sera collected in 1989 from the Daru-speaking area of southern Western Province, and further inland, in the Upper Fly area, the seroprevalence of JE appeared to be increasing, with $8 \%$ of sera positive in 1990-1991 and $28 \%$ positive in 1997 (JOHANSEN et al. 1997). In contrast, the prevalence of antibodies to MVE virus appears to have decreased from $24 \%$ in 1992 to $4 \%$ in 1997 , whereas the prevalence of antibodies to KUN virus has remained stable over this period (JOHANSEN et al. 1997).

In addition to the increasing activity of JE virus observed in Western Province, it also appears that the geographic distribution of the virus is expanding in PNG. Until recently, antibodies to JE virus had been detected in Gulf Province $(17 \%$ seropositivity to JE virus at Kerema in 1993) and Southern Highlands Province (4\% seropositivity at Lake Kutubu in 1994), but not in sera collected from people living in northern or eastern PNG (JoHANSEN et al. 1997). However there is some evidence to indicate that JE may have spread further east, jumping to Milne Bay Province, where nearly $40 \%$ of sera collected just after an outbreak of encephalitis on Normanby Island in late 1997 were positive to JE virus, and unconfirmed cases of JE were reported from Alotau, capital of the Province (MACKEnZIE 1999a). A survey of domestic pigs near Vanimo in West Sepik Province on the north coast of PNG has also revealed evidence of JE infection, suggesting that JE virus may have crossed the central mountain range or moved eastwards from northern Irian Jaya (J. Lee, personal communication). 
Three isolates of JE virus have been obtained from $C x$. sitiens subgroup mosquitoes, including C.x. annulirostris and Cx. palpalis, in Western Province (MACKenZie 1999b; JohAnSEn et al. 2000). An isolate was obtained in 1997 at Lake Murray, and two isolates were obtained in 1998 at Balimo and Abam. These three JE isolates from PNG were almost identical to the 1995 and 1998 Torres Strait isolates, and shared the same 11-base deletion, providing strong evidence that the Torres Strait incursions were from southern PNG, and most probably from Western Province. Interestingly, two isolates of MVE virus and one of Sepik virus came from the same mosquito collections that yielded JE virus at Balimo, demonstrating that various flaviviruses were co-circulating at that site.

The first four cases of encephalitis caused by JE virus in PNG, two of which were fatal, were recognised at a mission hospital near Kiunga in late 1997-early 1998 (J. Oakley, S. Flew, C.A. Johansen, R.A. Hall, D. Phillips, J.S. Mackenzie, unpublished results). A case of encephalitis due to JE virus infection was also reported from the Timika area of Irian Jaya in 1997 (SPICER 1997), and subsequent serological studies demonstrated that several indigenous persons had antibodies to the virus (SPICER et al. 1999).

Thus the results of studies in PNG and Irian Jaya suggest that: (a) JE has been enzootic in parts of Western Province since at least 1989, and possibly elsewhere in PNG and Irian Jaya; (b) the virus appears to be actively and rapidly spreading in PNG; (c) clinical cases were first recognised in 1997, and it is probable that earlier cases, or cases elsewhere in PNG, would not have been recognised because of the paucity of medical and diagnostic facilities; (d) the first isolations of JE virus in PNG were obtained from $C x$. sitiens subgroup mosquitoes trapped in Western Province; and (e) sequence studies of the JE virus isolates have indicated that the incursions into the Torres Strait originated from Western Province.

\section{Vectors and Vertebrate Hosts: the Potential for Establishment in Australasia}

JE appears to have become established in New Guinea (Irian Jaya and PNG) and the eastern Indonesian archipelago, despite the presence of related flaviviruses (e.g. MVE and KUN). The propensity of JE to spread and colonise new areas suggests that JE virus will eventually become established in Australia. Indeed, recurrent JE activity on Badu (in 6 out of 7 years) indicates that it may be established in natural cycles there. Establishment requires the presence of suitable vectors and vertebrate hosts. The probable vector mosquito species and vertebrate hosts in PNG either occur in Australia or are closely related to similar species in Australia. This section explores these possible vectors and vertebrate hosts in more detail, both in terms of their involvement in JE transmission elsewhere or in transmission cycles of related flaviviruses in Australia. Once again there are parallels to be drawn with current studies being undertaken with WN virus in North America. 


\subsection{Entomological Studies: JE vectors in Australasia}

The primary vectors of JE virus in southeast Asia are rice field breeding mosquitoes of the Cx. vishnui subgroup, from which Cx. tritaeniorhynchus is the most important (reviewed by Rosen 1986; Burke and LeAKe 1988; VAughn and Hoke 1992; see chapter by Endy and Nisalak, this volume). However, most members of this complex do not occur in Australia. Consequently, since the 1995 outbreak, entomological investigations have been undertaken to incriminate the potential vectors of $\mathrm{JE}$ virus in the Australasian zoogeographical region.

To date, 53 isolates of JE virus have been obtained from mosquitoes collected from the Torres Strait, with 52 recovered from Badu, and a single isolate from Saibai. Of these isolates, 51 have been obtained from $C x$. annulirostris, implicating this species as the primary vector of JE virus in northern Australia (RITCHIE et al. 1997; Johansen et al. 2001; C.A. Johansen, A.F. van den Hurk, D.J. Nisbet, S.A. Ritchie, J.S. Mackenzie, unpublished results). In addition, three isolates of JE virus were obtained from Cx. sitiens subgroup mosquitoes collected in PNG, including CX. annulirostris (JOHANSEN et al. 2000). To date, no isolates have been obtained from mosquitoes collected in Cape York Peninsula (vAN DEN HuRk et al. 2001a; C.A. Johansen, A.F. van den Hurk, D.J. Nisbet, S.A. Ritchie, J.S. Mackenzie, unpublished results). Vector competence experiments demonstrated that a Queensland strain of $C x$. annulirostris can become infected and transmit JE virus to susceptible hosts (A.F. van den Hurk, R.A. Hall, S.A. Ritchie, J.S. Mackenzie, unpublished results).

The $C x$. sitiens subgroup is a complex of morphologically similar species, which includes $C x$. sitiens, $C x$. palpalis and $C x$. annulirostris in northern Australia (MARKs 1982; LeE et al. 1989). Cx. palpalis is relatively uncommon in northern Queensland, but collections from Lake Murray and Balimo in the Western Province of PNG in 1997 comprised approximately $90 \%$ Cx. palpalis. The Lake Murray collections subsequently yielded an isolate of JE virus, suggesting that $C x$. palpalis could be a vector, particularly during periods of below average rainfall (CHAPMAN et al. 2000; JoHANSEN et al. 2000). No isolates have been obtained from Cx. sitiens from northern Australia or PNG, although JE has been isolated from this species in Malaysia (Vythilingam et al. 1994, 1995). However, vector competence experiments with a Queensland strain of $C x$. sitiens demonstrated that this species can readily become infected and transmit JE virus to susceptible mice (A.F. van den Hurk, R.A. Hall, J.S. Mackenzie, unpublished results). It is not surprising that $C x$. annulirostris is the most important vector of JE virus in the Australasian region. It had been implicated as the major vector during an outbreak on Guam in 1947 (then classified as $C x$. annulirostris marinae), and was subsequently shown to be a competent laboratory vector (Hurlburt and Thomas 1949; ReEves and Rudnick 1951). Cx. annulirostris is considered to be the major fresh-water vector of arboviruses in Australia, particularly MVE and KUN viruses (MACKENZIE et al. 1994; Russell 1995; Russell and Dwyer 2000).

A single isolate of JE virus was obtained from Ochlerotatus vigilax collected from Badu in 1998 (JOHANSEN et al. 2001). Laboratory studies confirmed that this 
species can become infected with JE virus, with $90 \%$ of infected females having a disseminated infection (A.F. van den Hurk, R.A. Hall, J.S. Mackenzie, unpublished results). Oc. vigilax is prevalent throughout much of coastal Australia and is an important vector of Australian arboviruses (MACKENZIE et al. 1994; RuSSELL 1995). Female Oc. vigilax lay desiccation-resistant eggs in saltmarshes or mangroves; eggs hatch after flooding by tides or rainfall. It is possible that this species may play a role in the maintenance of JE virus by vertical transmission, as has been demonstrated with other Ochlerotatus species in Asia (RosEN et al. 1978; TAKASHIMA and Rosen 1989).

During the 2000 incursion, a single isolate of JE virus was obtained from $C x$. gelidus (VAN DEN HURK et al. 2001b). This species has only recently been recognised in northern Australia (Whelan et al. 2000; Muller et al. 2001), although it may have been present since at least 1994, but misidentified as the morphologically similar Cx. vicinus (RITCHIE et al. 2001). In Southeast Asia, Cx. gelidus is an important vector of JE virus, as demonstrated by the numerous isolates obtained from this species (Gould et al. 1974; Simpson et al. 1974; Mourya et al. 1989; Peiris et al. 1992; Vythilingam et al. 1995) and experimental infection studies (Gould et al. 1962).

Several other mosquito species occur in Australia that could be potential JE virus vectors. Other species from which JE virus has been isolated in southeast Asia and found in Australia include Cx. p. quinquefasciatus, Cx. whitmorei, Cx. bitaeniorhynchus, Man. uniformis, Aedes lineatopennis and Ae. aegypti (LIEN et al. 1980; Mourya et al. 1989; TAN et al. 1993; HA et al. 1994; Peiris et al. 1994; VythiLINGAM et al. 1997). Furthermore, MVE virus has been isolated from Cx. p. quinquefasciatus (LIEHNE et al. 1981), and Cx. p. australicus (MARshall et al. 1982). In addition, MVE virus has been isolated from Oc. normanensis and Oc. tremulus males in Western Australia (Вrоoм et al. 1989, 1995), while Oc. sagax and Verrallina funerea have been implicated in MVE virus transmission by experimental infection studies (KAY et al. 1977, 1989). Like Oc. vigilax, these floodwater species may assist in the overwintering of JE virus by persistence in desiccation-resistant eggs.

\subsection{Vertebrate Hosts of JE and JE Serogroup Viruses in Australasia}

Perhaps the most important vertebrate in JE virus transmission cycles, and the major amplifier host in Asia, is the pig (KomAdA et al. 1968; SCHERER et al. 1959b). Not only do pigs develop viraemias of high magnitude, but they have a high turnover, making them ideal vertebrate hosts. In Australia, most commercial piggeries are located in southern regions. There is evidence that domestic pigs in Australia can become infected with flaviviruses. A study in Queensland in the late 1960s-early 1970s revealed that pigs in commercial piggeries were infected with flaviviruses, including KUN and ALF viruses (Spradbrow 1972). Further recent evidence for the involvement of pigs in flavivirus transmission in Australia is the regular seroconversions to $\mathrm{MVE}$ and $\mathrm{KUN}$ viruses in sentinel pigs at various locations in Cape York, the Northern Territory and northern Western Australia 
[J. Lee, Australian Quarantine and Inspection Service (AQIS), unpublished results]. Antibodies specific for JE were detected in juvenile semi-domestic pigs in Cape York near the mouth of the Mitchell River, shortly after the occurrence of the only mainland case of JE, confirming that JE virus transmission cycles had occurred in the area (HANNA et al. 1999). However, given the distribution of most large commercial piggeries in Australia, domestic pigs are unlikely to have a role in establishment of JE virus transmission cycles unless it spreads to southern regions of the continent.

In contrast, feral pigs are major vertebrate pests in Australia and PNG. The highest densities of feral pigs are found in the north and northeast of Australia (Choquenot et al. 1996; Strahan 1995). Pigs were introduced into New Guinea approximately 6,000 years ago, and are now abundant as feral and semi-domesticated populations (FLANNERY 1990). Feral pigs can breed year round, and when conditions are favourable, they can produce up to six litters per year (STRAHAN 1995). The role of feral pigs in flavivirus transmission in Australia and New Guinea is not well understood, although GARD et al. (1976) revealed that they could be infected with MVE and KUN viruses. More recently, neutralising antibody to JE and MVE viruses were detected in semi-domesticated pigs at various locations in Western Province of PNG not long after the outbreak of JE virus in the Torres Strait in 1995 (J. Shield, DPI, unpublished results), and serological evidence of JE virus infection has since also been detected in pigs near Vanimo in East Sepik Province of PNG (J. Lee, AQIS, unpublished results).

Of the other domestic animals common in northern Australia, most are believed to be dead-end hosts, and not involved in transmission cycles. Only horses are susceptible to a fatal encephalitis, although as in humans, most infections are inapparent (reviewed by Ellis et al. 2000). Other domestic species, such as cattle, buffalo, and dogs do not exhibit disease. Cattle and buffalo, although often infected by JE virus as demonstrated by a high prevalence of antibodies in many parts of Asia, do not develop high titres of viraemia (JoHNSEN et al. 1974; ILKAL et al. 1988), and may even serve to reduce the level of JE virus transmission in an area where they are abundant through zooprophylaxis (CAREY et al. 1969). They (and goats) have also been suggested as good predictors of human infection risk (PEIRIS et al. 1993), and indeed are currently being explored as possible sentinels for JE in northern Australia in place of pigs. Nevertheless, in central Java where pigs are less common, JE virus was isolated from seven species of mosquitoes trapped in cattle shelters, suggesting that cattle may be involved in some natural transmission cycles in Indonesia (TAN et al. 1993).

The major avian hosts of JE in Asia are ardeid birds. The Black-crowned night heron (Nycticorax nycticorax) is considered to be the most important maintenance host, although other ardeids such as egrets and herons as well as other non-passerine and passerine birds have been implicated in various studies. Experimental infections and transmission studies have also confirmed the role of certain ardeid species in JE virus transmission (SOMAN et al. 1977; BoYLE et al. 1983). Duration of viraemia generally lasts between 1 and 7 days post-infection, depending on the species (BANERJEe et al. 1979; Boyle et al. 1983; Soman et al. 1977). Viraemic 
migratory or vagrant birds are thought to be a method by which JE virus is introduced into new areas. Various species of herons, egrets, bitterns, ducks and cormorants found in Australia and PNG have been implicated in JE virus transmission in other countries, but no evidence of antibodies to JE have yet been detected in Australia. Previous serological surveys have detected antibody to MVE virus in many species of birds in Australia, especially waterbirds and psittacines, possibly providing clues to potential vertebrate hosts of JE virus (LIEHNE et al. 1976; Marshall et al. 1982).

Many species of marsupials occur in the Australasian zoogeographic region which could have the potential to act as vertebrate hosts for JE and other flaviviruses. Indeed, marsupials are believed to be the vertebrate hosts of KOK, STR and EH viruses (DoherTy 1972; DoherTy et al. 1964; MACKenZIE et al. 1994). Furthermore, marsupials are a common source of bloodmeals for $C x$. annulirostris mosquitoes (KAY et al. 1979). Laboratory infections with MVE virus showed the virus could reach high titres in the Eastern grey kangaroo, but not the Agile wallaby (KAy et al. 1985b). Early data from the Australian Animal Health Laboratory in Geelong, Australia, suggests that Eastern grey kangaroos, Tammar wallabies and Agile wallabies either failed to develop, or developed low levels of viraemia during experimental infections with JE virus, but possums developed higher viraemias which might be sufficient to infect mosquitoes (P.W. Daniels, D. Middleton, D. Boyle, K. Newberry, D. Williams, R. Lunt, unpublished results).

$\mathrm{JE}$ virus has been isolated from a number of bats belonging to the Orders Microchiroptera and Megachiroptera in Asia, but almost all studies of the role of bats in maintenance and transmission have been carried out on Microchiroptera. Most of the extensive early studies were reviewed by Sulkin and Allen, (1974). Some species from which JE has been isolated also occur in northern Australia and New Guinea, such as the Common bentwing bat (Miniopterus schreibersii). Bats make good potential vertebrate hosts because of their long viraemia, the lack of encephalitis despite high titres of virus in the brain, and their ability to sequester infectious virus in an inactive state in brown adipose fat during hibernation (reviewed by Sulkin and Allen 1974). Stanley and Choo (1964) found HI antibodies to MVE virus in pooled insectivorous bat sera collected in central Western Australia, however another study in northern Queensland failed to find any evidence of MVE infection in 23 fruit bats (DOHERTY et al. 1964). The involvement of Megachiroptera, or fruit bats, in the ecology of JE virus was first indicated from studies in Thailand in which neutralising antibodies to JE were observed in 22 of 245 Cynopterus brachyotis (P.K. Russell 1968, personal communication to SulKIN and Allen 1974). This species is widely distributed in southeastern Asia from Thailand through Peninsula Malaysia to Singapore, Sumatra, Sabah, Sarawak, Kalimantan, Sulawesi, Lombok, and the Philippines. Experimental infection has been studied in two species in India, Rousettus leschenaulti (BANERJEE et al. 1979) and Cynopterus sphinx (BANERJEe et al. 1984). The former study demonstrated a low level of viraemia after subcutaneous inoculation of JE virus lasting up to 9 days. In the latter study, bats were infected intra-muscularly with JE virus and, during the subsequent viraemic phase, $C x$. bitaeniorhynchus and $C x$. 
tritaeniorhynchus were allowed to feed on them. Transmission was observed between bats, from bats to chickens, and from chickens to bats. Thus frugivorous bats are good candidates for virus maintenance and, potentially, virus movement.

\section{Possible Mechanisms of Spread of JE into and within Australasia}

The lack of information about flaviviral activity in Wallacea, and the imprecise nature of flaviviral seroepidemiology, make it difficult to determine the mechanisms of spread of JE virus from the Oriental to the Australasian zoogeographic region. A single incursion into PNG or Irian Jaya from the western Indonesian archipelago through an infected migrant bird or traveller appears unlikely, the former because migration is normally a north-south movement rather than a west-east movement, and the latter because it is doubtful whether viraemia levels in people are sufficient to re-infect mosquitoes. Two mechanisms can be suggested, however, including: (a) movement through viraemic livestock during trans-migration or re-settlement programmes; or (b) gradual movement through natural mosquito-bird and mosquito-pig cycles. The latter seems most likely, with the virus 'island-hopping' in a gradual movement eastwards, arriving unannounced and undetected in PNG and Irian Jaya by 1989 or earlier. In support of this explanation, a JE virus strain was isolated from mosquitoes trapped on Flores Island in 1981 (J.G. Olson, unpublished results), and seropositive pigs were observed in Timor and Irian Jaya in the period 1989-1991 (P.W. Daniels, I. Sandow, unpublished results).

JE was first detected in the Torres Strait of northern Australia in 1995 when human cases occurred. Whether silent incursions had occurred previously is not known. However, it has been detected every year in the wet season (January to April) since 1995, except 1999, through sentinel pig seroconversions, virus isolations or human cases (Table 1), suggesting that movement from PNG into the

Table 1. Known incursions of Japanese encephalitis virus into Australia based upon porcine and human serology and mosquito virus isolates ${ }^{\mathrm{a}}$

\begin{tabular}{llll}
\hline & \multicolumn{2}{l}{ Southernmost limit of known JE activity } & \\
\cline { 2 - 4 } Year & Region & Location & Distance from \\
& & & 100 \\
\hline 1995 & Torres Strait & Badu & 5 \\
1996 & Torres Strait & Saibai & 5 \\
1997 & Torres Strait & Saibai & 675 \\
1998 & Cape York & Mitchell R. & \\
1999 & None known & & 100 \\
2000 & Torres Strait & Badu & 100 \\
2001 & Torres Strait & Badu & \\
\hline
\end{tabular}

${ }^{\text {a }}$ Based on data from HANNA et al. (1997, 1999), SHIELD et al. (1996), and unpublished results from AQIS, University of Queensland and Queensland Health. 
Torres Strait is relatively common. Incursions into northern mainland Australia (Cape York) may be less frequent, although information is more difficult to obtain. Furthermore, JE virus activity was synchronous, with the onset of each human case in Badu and the Mitchell River, occurring within 5 days of each other (HANNA et al. 1999). Several mechanisms could introduce JE virus into Australia including: (a) via viraemic pigs; (b) via other viraemic, mobile non-avian vertebrates (bats, etc.); (c) via viraemic birds; or (d) via wind-blown viraemic mosquitoes or other infected insects.

JE virus was probably not introduced into the Torres Strait via infected pigs (HANNA et al. 1996b); AQIS prohibits transport of pigs from PNG into the Torres Strait, and the broad, sudden appearance of JE activity does not support this possibility. Other large vertebrates, such as humans and dogs, do not develop sufficient viraemias to readily transmit JE virus to mosquitoes (BURKE and LEAKE 1988; JOHNSEN et al. 1974). While bats are capable of infecting mosquitoes with JE virus (Burke and LeAKe 1988), and some, notably flying foxes (Pteropus sp.), move between PNG and the Torres Strait (G.C. Richards and L.S. Hall, unpublished results), their role in enzootic transmission and dispersal of JE virus in Australasia is unknown. Numerous birds are known to develop infective viraemias of JE virus (BUESCHER et al. 1959), especially ardeid birds, and infected ardeid birds are suspected of initiating new transmission cycles (SCHERER et al. 1959a). Ardeid birds, such as the Nankeen night heron (Nycticorax caledonicus) and various egrets are known or likely hosts for JE virus, and migrants or vagrants commonly traverse the Torres Strait (Draffen et al. 1983; P. Driscoll, personal communication). Clearly migratory birds could have introduced JE virus into the Torres Strait and Cape York. However, the sudden, widespread occurrence of JE across the Torres Strait, especially in the volcanic eastern islands that lack wetlands attractive to wading birds, suggest that other mechanisms are also responsible for introducing JE virus into Australia (GARnett and SMith 1997; RitchiE and ROCHESTER 2001).

Circumstantial evidence suggests that wind-borne, infected $C x$. annulirostris could have imported JE virus into Australia. Kite trap studies have collected numerous female Cx. tritaeniorhynchus, the primary JE vector in SE Asia, in India and China (REYNOLDs et al. 1996; MiNG et al. 1993) and it has also been collected on ships out to sea, suggesting a wind blown origin (HAYASHI et al. 1975). Cx. annulirostris have been collected in kite traps at up to $310 \mathrm{~m}$, travelling up to $648 \mathrm{~km}$, in New South Wales, Australia (KAY and FArrow 2000). Furthermore, allozyme analysis indicates significant gene flow between populations of $C x$. annulirostris from southern PNG, the Torres Strait and the Cape York Peninsula, suggesting widespread dispersal (H.F. Chapman, S.A. Ritchie and B.H. Kay unpublished results). However, no $C x$. annulirostris were collected using balloonmounted traps approximately 100m above ground in January-February 2000 on Saibai island, although collections were made during a period of weak monsoonal winds (C.A. Johansen, S.A. Ritchie, R.A. Farrow, unpublished results). This suggests that strong surface winds are necessary to induce mosquito dispersal above the surface boundary layer. 
RITCHIE and Rochester (2001) used a simulation model to investigate if conditions were conducive to transport mosquitoes (potentially infected with JE virus) from New Guinea to northern Australia. The outbreaks of JE in 1995 and, especially, 1998, were preceded by strong northerly winds capable of carrying mosquitoes from PNG to Badu and to the Mitchell River in 1995 and 1998, respectively. These winds were created by strong low pressure systems southwest of the Torres Strait (Fig. 3). Introduction of JE virus at this time would have been sufficient for two cycles of virus amplification before the advent of human cases (Konno et al. 1964; Ritchie and Rochester, 2001). Concurrently, southern PNG had very high populations of $C x$. sitiens group mosquitoes from which JE virus was isolated (JOHANSEN et al. 2000), probably due to a severe drought in which many rivers dried to form stagnant pools.

Thus, at this time, we have no direct proof of how JE virus was introduced into Australia, although mosquitoes and/or birds are likely to have been involved.
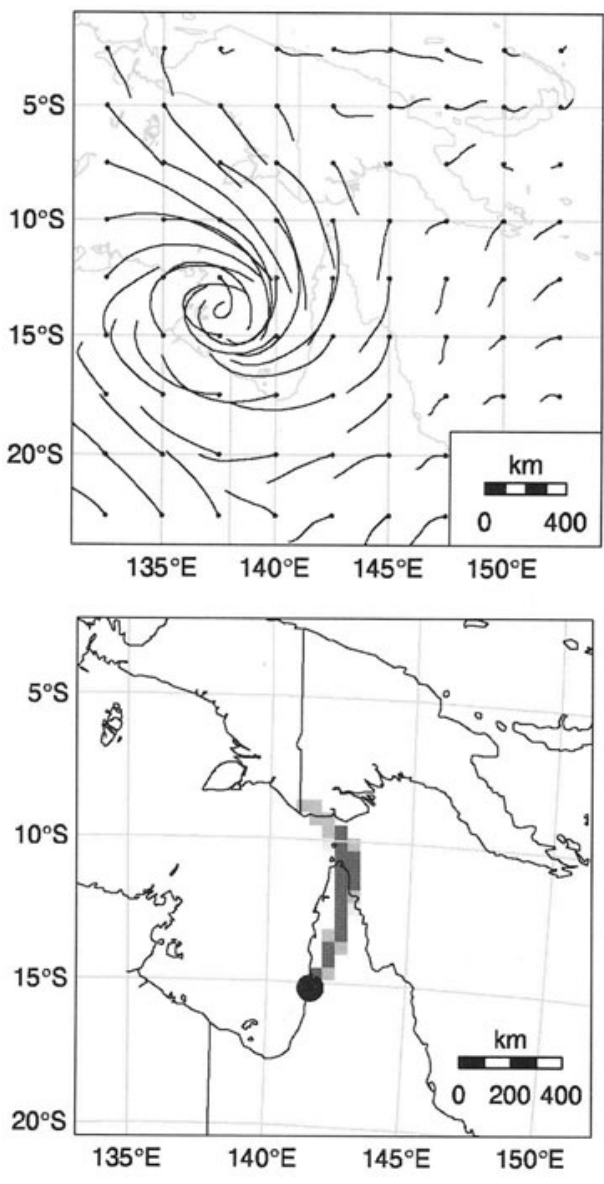

Fig. 3. The estimated flight trajectories at $100 \mathrm{~m}$ (a) and backtrack simulations (b) of mosquitoes from the Mitchell River for 27 December 1997. The pixel shade represents the number of back trajectory endpoints per $\mathrm{km}^{2}$ per million simulated mosquito trajectories, with white, 0; light, <10; medium, 1-20; and dark, >20. (From Ritchie and Rochester, in press 
Finally, nine Culicoides sp. were collected in the same aerial samples on Saibai that had not yielded Culex mosquitoes (C.A. Johansen, S.A. Ritchie and R.A. Farrow, unpublished results). It has been established that wind-blown Culicoides were probably responsible for incursions of bluetongue virus from Indonesia into northern Australia (Melville et al. 1997), and as there has been one report of the isolation of $\mathrm{JE}$ from a biting midge Forcipomyia taiwana (formerly Lasiohelia taiwana) (WU and WU 1957), it is tempting to speculate that perhaps biting midges could be involved in JE transmission and dispersal in Australasia.

\section{The Potential of JE to Spread into the Pacific}

The spread of JE to new areas in India and Pakistan in the west and Australasia in the east indicates that other areas of the Pacific could be at risk of JE in the future. Certainly, many islands have potential vectors and vertebrate hosts for JE virus transmission. Fortunately, the risk, in most cases, appears to be small. The island groups most at risk are those closest to PNG, including Bougainville and New Britain. If JE became established on Bougainville Island, it is likely that it would subsequently spread to the Solomon Islands, especially the larger islands in the Solomon Sea. Subsequent spread to other Pacific countries, such as Fiji, Vanuatu and New Caledonia, however, remains small because of distance.

Nevertheless, the introduction of JE into the north Pacific islands of Guam (HAMmON et al. 1958) and Saipan (PAul et al. 1993) resulted in outbreaks with human fatalities, so the possibility of long-distance spread cannot be discounted completely, and countries with a pig culture, such as Vanuatu, would perhaps be at most risk of human disease. JE virus failed to become established in endemic cycles following the outbreaks on Guam and Saipan, and it would seem that the risk of virus establishment would be negligible.

Acknowledgements. Much of the work describing the emergence of Japanese encephalitis virus in Papua New Guinea, the Torres Strait and northern Australia was supported by grants from the National Health and Medical Research Council, Queensland Health, and the Australian Quarantine and Inspection Service.

\section{References}

Aaskov JG, Phillips DA, Weimers MA (1993) Possible clinical infection with Edge Hill virus. Trans Royal Soc Trop Med Hyg 87:452-453

Anderson SG, Price AVG, Nanadai-Koia, Slater K (1960) Murray Valley encephalitis in Papua and New Guinea. II. Serological survey. Med J Aust 2:410-413

Atmosoedjono S, Van Peenen PF, Joseph SW, Saroso JS, See R (1973) Observations on possible Culex arbovirus vectors in Djakarta, Indonesia. Southeast Asian J Trop Med Publ Health 4:108-112 
Banerjee K, Ilkal MA, Deshmukh PK (1984) Susceptibility of Cynopterus sphinx (frugiorous bat) and Suncus murinus (house shrew) to Japanese encephalitis virus. Indian J Med Res 79:8-12

Banerjee K, Ilkal MA, Bhat HR, Sreenivasan MA (1979) Experimental viraemia with Japanese encephalitis virus in certain domestic and peridomestic vertebrates. Ind J Med Res 70:364-368

Bennett NM (1976) Murray Valley encephalitis, 1974: clinical features. Med J Aust 2:446-450

Bowen ET, Simpson DI, Platt GS, Way HJ, Smith CE. Ching CY, Casals J (1970) Arbovirus infections in Sarawak: the isolation of Kunjin virus from mosquitoes of the Culex pseudovishnui group. Ann Trop Med Parasitol 64:263-268

Boyle DB, Dickerman RW, Marshall ID (1983) Primary viraemia responses of herons to experimental infection with Murray Valley encephalitis, Kunjin and Japanese encephalitis viruses. Aust J Exp Biol Med Sci 61:655-664

Broom AK, Lindsay MDA, Johansen CA, Wright AE, Mackenzie JS (1995) Two possible mechanisms for survival and initiation of Murray Valley encephalitis virus activity in the Kimberly region of Western Australia. Am J Trop Med Hyg 53:95-99

Broom AK, Wright AE, Mackenzie JS, Lindsay MD, Robinson D (1989) Isolation of Murray Valley encephalitis and Ross River viruses from Aedes normanensis (Diptera: Culicidae) in Western Australia. J Med Entomol 26:100-103

Buescher EL, Scherer WF, Rosenberg MZ, McClure HE (1959). Ecologic studies of Japanese encephalitis virus in Japan. III. Infection and antibody responses of birds. J Immunol 83:605-613

Buhl MR, Black FT, Andersen PL, Laursen A (1996) Fatal Japanese encephalitis in a Danish tourist visiting Bali for 12 days. Scand J Infect Dis 28:189

Burke DS, Leake CJ (1988) Japanese encephalitis. In: Monath TP (ed) The Arboviruses: Epidemiology and Ecology, Volume III. CRC Press, Boca Raton, pp 63-92

Carey DE, Myers RM, Reuben R, Webb JKG (1969) Japanese encephalitis in South India. A summary of recent knowledge. J Ind Med Assoc 52:10-15

Chapman HF, Kay BH, Ritchie SA, van den Hurk AF, Hughes JM (2000) Definition of species in the Culex sitiens subgroup (Diptera: Culicidae) from Papua New Guinea and Australia. J Med Entomol 37:736-742

Chen W-R, Tesh RB, Rico-Hesse R (1990) Genetic variation of Japanese encephalitis virus in nature. J Gen Virol 71:2915-2922

Chen W-R, Rico-Hesse R, Tesh RB (1992) A new genotype of Japanese encephalitis virus from Indonesia. Am J Trop Med Hyg 47:61-69

Choquenot D, McIlroy J, Korn T (1996) Managing vertebrate pests: feral pigs. Australian Government Publishing Service, Canberra

Coelen RJ, Mackenzie JS (1988) Genetic variation of Murray Valley encephalitis virus. J Gen Virol 69:1903-1912

Coelen RJ, Lawson MA, Flynn LM, Mackenzie JS (1989) Genome variation of Australian flaviviruses. Arbovirus Res Aust 5:55-58

Cordova SP, Smith DW, Broom AK, Lindsay MD, Dowse GK, Beers MY (2000) Murray Valley encephalitis in Western Australia in 2000, with evidence of southerly spread. Commun Dis Intell 24:368-372

Dhanda V, Thenmozhi V, Hiriyan J, Arunachalam N, Batasubramanian A, Ilango A, Gajanana A (1997) Virus isolation from wild-caught mosquitoes during a Japanese encephalitis outbreak in Kerala in 1996. Indian J Med Res 106:4-6

Doherty RL (1972) Arboviruses of Australia. Aust Vet J 48:172-180

Doherty RL, St George TD, Carley JG (1973) Arbovirus infections of sentinel cattle in Australia and New Guinea. Aust Vet J 49:574-579

Doherty RL, Carley JG, Gorman BM (1964) Studies of arthropod-borne virus infections in Queensland. IV. Further serological investigations of antibodies to Group B arboviruses in man and animals. Aust J Exp Biol Med Sci 42:149-164

Draffan RDW, Garnett ST, Malone GT (1983) Birds of the Torres Strait: an annotated biogeographical analysis. Emu 83:207-234

Ellis PM, Daniels PW, Banks DJ (2000) Japanese encephalitis. Vet Clin North Am Equine Pract 16: 565-578

Essed WCAH, Van Tongeran HAE (1965) Arthropod-borne virus infections in Western New Guinea. I. Report of a case of Murray Valley encephalitis in a Papuan woman. Trop Geogr Med 1:52-55

Flannery T (1990) The Mammals of New Guinea. Robert Brown and Associates Pty. Ltd, Carina, Queensland 
French EL, Anderson SG, Price AVG, Rhodes FA (1957) Murray Valley encephalitis in New Guinea. I. Isolation of Murray Valley encephalitis virus from the brain of a fatal case of encephalitis occurring in a Papuan native. Am J Trop Med Hyg 6:827-834

Gard GP, Giles JR, Dwyer-Gray RJ. Woodroofe GM (1976) Serological evidence of inter-epidemic infection of feral pigs in New South Wales with Murray Valley encephalitis virus. Aust J Exp Biol Med Sci 54:297-302

Garnett S, Smith R (1997) A second record of a papuan species of paradise kingfisher in the Torres Strait and its relevance to the dissemination of Japanese encephalitis. Sunbird 27:83-84

Gould DJ, Barnett HC, Suyemoto W (1962) Transmission of Japanese encephalitis virus by Culex gelidus Theobald. Trans R Soc Trop Med Hyg 56:429-435

Gould DJ, Edelman R, Grossman RA, Nisalak A, Sullivan MF (1974) Study of Japanese encephalitis virus in Chiangmai Valley, Thailand. IV. Vector studies. Am J Epidemiol 100:49-56

Ha DQ, Huong VTQ, Loan HTK, Deubel V (1994) Current situation of Japanese encephalitis in the south of Vietnam, 1976-1992. Trop Med 36:202-214

Hammon WM, Tigertt WD, Sather GE (1958). Epidemiologic studies of concurrent "virgin" epidemics of Japanese B encephalitis and of mumps on Guam, 1947-1948, with subsequent observations including dengue, through 1957. Am J Trop Med Hyg 7:441-68

Hanna J, Barnett D, Ewald D (1996a) Vaccination against Japanese encephalitis in the Torres Strait. Comm Dis Intell 19:447

Hanna JN, Ritchie SA, Phillips DA, McBride WJ, Hills SL, van den Hurk A (2001) An epidemic of dengue 3 in far north Queensland, 1997-1999. Med J Aust 174:178-182

Hanna JN, Ritchie SA, Phillips DA, Shield J, Bailey MC, Mackenzie JS, Poidinger M, McCall BJ, Mills PA (1996b) An outbreak of Japanese encephalitis in the Torres Strait, Australia, 1995. Med J Aust 165:256-260

Hanna JN, Ritchie SA, Phillips DA, Lee JM, Hills SL, Van Den Hurk AF, Pyke AT, Johansen CA, Mackenzie JS (1999) Japanese encephalitis in North Queensland, 1998. Med J Aust 170:533-536

Hawkes RA, Boughton CR, Naim HM, Wild J, Chapman B (1985) Arbovirus infections of humans in New South Wales. Seroepidemiology of the flavivirus group of togaviruses. Med J Aust 143:555-561

Hayashi K, Mifune K, Shichijo A, Suzuki H, et al. (1975) Ecology of Japanese encephalitis virus in Japan. III. The results of investigation in Amami Island, southern part of Japan. Trop Med 17: $129-142$

Heinz FX, Collett MS, Purcell RH, Gould EA, Howard CR, Houghton M, Moormann RJM, Rice CM, Thiel HJ (2000) Flaviviridae. In: van Regenmortel MHV, Fauquet CM, Bishop DHL, Carstens EB, Estes MK, Lemon SM, Maniloff J, Mayo MA, McGeoch DJ, Pringle CR, Wickner RB (eds) Virus Taxonomy. Classification and nomenclature of viruses. 7th Report of the International Committee for the Taxonomy of Viruses. Academic Press, San Diego, pp. 859-878

Hotta S, Aoki H, Yasui T, Samoto S (1967) Virologic-epidemiological studies on Indonesia. Survey of anti-arboviral antibodies in sera from residents of Lombok, Sumatra and Djawa. Kobe J Med Sci 13:221-234

Hotta S, Aoki H, Samoto S, Yasui T, Kawabe M (1970a) Virologic-epidemiological studies on Indonesia. II. Measurement of anti-arbovirus antibodies in sera from residents of Lombok, South Sumatra, and West Java, in comparison with results concerning sera from residents of Japanese main islands. Kobe J Med Sci 16:215-234

Hotta S, Aoki H, Samoto S, Yasui T, Noerjasin B (1970b) Virologic-epidemiological studies on Indonesia. III. HI antibodies against selected arboviruses (Groups A and B) in human and animal sera collected in Surabaja, East Java, in 1968. Kobe J Med Sci 16:235-250

Hurlburt HS, Thomas JI (1949) Potential vectors of Japanese encephalitis in the Caroline Islands. Am J Trop Med 29:215-217

Igarashi A, Tanaka M, Morita A, Takasu T. Ahmed A, Ahmed A, Akram DS, Waqar MA (1994) Detection of West Nile and Japanese encephalitis viral genome sequences in cerebrospinal fluid from acute encephalitis cases in Karachi, Pakistan. Microbiol Immunol 38:827-830

Ilkal MA, Dhanda V, Rao BU, George S, Mishra AC, Prasanna Y, Gopalkrishna S, Pavri KM (1988) Absence of viraemia in cattle after experimental infection with Japanese encephalitis virus. Trans $R$ Soc Trop Med Hyg 82:628-631

Johansen CA, van den Hurk AF, Pyke AT, Zborowski P, Phillips DA, Mackenzie JS, Ritchie SA (2001) Entomological investigations of an outbreak of Japanese encephalitis virus in the Torres Strait, Australia, in 1998. J Med Entomol (in press)

Johansen CA, van den Hurk AF, Ritchie SA, Zborowski P, Nisbet DJ, Paru R, Bockarie MJ, Macdonald J, Drew AC, Khromykh TI, Mackenzie JS (2000) Isolation of Japanese encephalitis virus from 
mosquitoes (Diptera: Culicidae) collected in the Western Province of Papua New Guinea, 1997-1998. Am J Trop Med Hyg 62:631-638

Johansen C, Ritchie S, van den Hurk A, Bockarie M, Hanna J, Phillips D, Melrose W, Poidinger M. Scherret J, Hall R, Mackenzie J (1997) The search for Japanese encephalitis virus in the Western Province of Papua New Guinea. Arbovirus Res Aust 7:131-136

Johnsen DO, Edelman R, Grossman RA, Maungman D, Pomsdhit J, Gould DJ (1974) Study of Japanese encephalitis virus in the Chiangmai Valley. Thailand. V. Animal infections. Am J Epidemiol 100:57-68

Kanamitsu M, Taniguchi K, Urasawa S, Ogata T, Wada Y, Wada Y, Saroso JS (1979) Geographic distribution of arbovirus antibodies in indigenous human populations of the Indo-Australian Archipelago. Am J Trop Med Hyg 28:351-363

Karabatsos N (ed.) (1985) International Catalogue of Arboviruses, 3rd Edition. American Society of Tropical Medicine and Hygiene, San Antonio, Texas

Kay BH and Farrow RA (2000) Mosquito (Diptera: Culicidae) dispersal: Implications for the epidemiology of Japanese and Murray Valley encephalitis viruses in Australia. J Med Entomol 37:797-801

Kay BH, Boreham PFL, Williams GM (1979) Host preferences and feeding patterns of mosquitoes (Diptera: Culicidae) at Kowanyama, Cape York Peninsula, northern Queensland. Bull Entomol Res 69:441-457

Kay BH, Carley JG, Filippich C (1977) The multiplication of Queensland and New Guinean arboviruses in Aedes funereus (Theobald) (Diptera: Culicidae). J Med Entomol 13:451-453

Kay BH, Fanning ID, Mottram P (1989) The vector competence of Culex annulirostris, Aedes sagax and Aedes alboannulatus for Murray Valley encephalitis at different temperatures. Med Vet Entomol 3:107-112

Kay BH, Young PL, Hall RA, Fanning ID (1985b) Experimental infection with Murray Valley encephalitis virus. Pigs, cattle, sheep, dogs, rabbits, macropods and chickens. Aust J Exp Biol Med Sci 63:109-126

Komada K, Sasaki N, Inoue YK (1968) Studies of live attenuated Japanese encephalitis vaccine in swine. J Immunol 100:194-200

Konno J, Endo K, Agatsuma H, Ishida N (1964) Cyclic outbreaks of Japanese encephalitis among pigs and humans. Am J Trop Epidemiol 3:292-299

Lee DJ, Hicks MM, Griffiths M, Russell RC, Bryan JH, Marks EN (1989) The Culicidae of the Australasian Region. Entomology Monograph No.2. Vol. 7. Australian Government Publishing Service Press. Canberra

Lee VH, Atmosoedjono S, Rusmiarto S, Aep S, Semendra W (1983) Mosquitoes of Bali Island. Indonesia: common species in the village environment. Southeast Asian J Trop Med Publ Hlth 14:298-307

Liehne CG, Stanley NF, Alpers MP, Paul S, Liehne, PFS, Chan KH (1976) Ord River arboviruses serological epidemiology. Aust J Exp Biol Med Sci 54:505-512

Liehne PFS, Anderson S, Stanley NF, Liehne CG, Wright AE, Chan KH, Leivers S, Britten DK, Hamilton NP (1981) Isolation of Murray Valley encephalitis virus and other arboviruses in the Ord River Valley 1972-1976. Aust J Exp Biol Med Sci 59:347-356

Lien JC, Huang WC, Cross JH (1980) Japanese encephalitis virus surveillance in the Taipei area, Taiwan in 1978. Southeast Asian J Trop Med Publ Health 11:177-183

Lobigs M, Marshall ID, Weir RC, Dalgarno L (1986a) Genetic differentiation of Murray Valley encephalitis virus in Australia and Papua New Guinea. Aust J Exp Biol Med Sci 64:571-585

Lobigs M, Marshall ID, Weir RC, Dalgarno L (1988) Murray Valley encephalitis virus field strains from Australia and Papua New Guinea: studies on the sequence of the major epitope protein gene and virulence for mice. Virology 165:245-255

Macdonald WBG, Tink AR, Ouvrier RA, Menser MA, de Silva LM, Naim H, Hawkes RA (1989) Japanese encephalitis after a two-week holiday in Bali. Med J Aust 150:334-339

Mackenzie JS (1999a) The ecology of Japanese encephalitis virus in the Australasian region. Clin Virol (Japan) 27:1-17

Mackenzie JS (1999b) Emerging viral diseases: an Australian perspective. Emerg Infect Dis 5:1-8

Mackenzie JS, Cunningham A, Hueston L, LaBrooy J (1996a) Dengue in Australia. J Med Microbiol 45:159-161

Mackenzie JS, Smith DW, Broom AK; Bucens MR (1993) Australian encephalitis in Western Australia, 1978-1991. Med J Aust 158:591-595

Mackenzie JS, Poidinger M, Lindsay MD, Hall RA. Sammels LM (1996b) Molecular epidemiology and evolution of mosquito-borne flaviviruses and alphaviruses enzootic in Australia. Virus Genes 11: $225-237$

Mackenzie JS, Lindsay MD, Coelen RJ, Broom AK, Hall RA, Smith DW (1994) Arboviruses causing human disease in the Australasian zoogeographic region. Arch Virol 136:447-467 
Mackenzie JS. Poidinger M, Phillips D, Johansen CA. Hall RA. Hanna J, Ritchie S. Shield J, Graham R (1997a) Emergence of Japanese encephalitis virus in the Australasian region. In: Saluzzo JF, Dodet B (eds.) Factors in the Emergence of Arbovirus Diseases. Elsevier, Paris. pp. 191-201

Mackenzie JS, Chua KB, Daniels PW, Eaton BT, Field HE, Hall RA, Halpin K. Johansen CA, Kirkland PD, Lam SK, McMinn P, Nisbet DJ, Paru R. Pyke AT, Ritchie SA, Siba P, Smith DW. Smith GA, van den Hurk AF, Wang LF, Williams DT (2001) Emerging viral diseases of South-East Asia and the Western Pacific: a brief review. Emerg Infect Dis (in press)

Marks EN (1982) Recent taxonomic studies of Culex annulirostris and allied species and their possible significance for arbovirus research. Arbovirus Res Aust 3:146-151

Marshall ID (1988) Murray Valley and Kunjin encephalitis. In: Monath TP (ed.) The Arboviruses: Epidemiology and Ecology, Vol.III. CRC Press, Boca Raton, USA, pp. 151-189

Marshall ID, Woodroofe GM, Hirsch S (1982) Viruses recovered from mosquitoes and wildlife serum collected in the Murray Valley of south-eastern Australia, February 1974, during an outbreak of encephalitis. Aust J Exp Biol Med Sci 60:457-470

Melville LF, Pritchard LI, Hunt NT, Daniels PW, Eaton B (1997) Genotypic evidence of incursions of new strains of bluetongue viruses in the Northern Territory. Arbovirus Res Australia 7:181-186

Ming J-G, Hua J, Riley JR, Reynolds DR, Smith AD, Ren-Lai W, Ji-Yi C, Xia-Nian C (1993) Autumn southward 'return' migration of the mosquito Culex tritaeniorhynchus in China. Med Vet Entomol 7:323-327

Monath TP, Heinz FX (1996) Flaviviruses. In: Fields BN, Knipe DM, Howley PM, Chanock RM, Melnick JL, Monath TP. Roizman B, Straus SE (eds) Fields Virology, Volume 1, 3rd Edition. Lippincott-Raven Publishers, Philadelpia, pp 961-1034

Mourya DT, Ilkal MA, Mishra AC, Jacob PG, Pant U, Ramanujam S, Mavale MS, Bhat HR, Dhanda V (1989) Isolation of Japanese encephalitis virus from mosquitoes collected in Karnataka state, India from 1985 to 1987. Trans R Soc Trop Med Hyg 83:550-552

Muller MJ, Montgomery BL, Ingram A, Ritchie SA (2001) First records of Culex gelidus from Australia. J Am Mosq Control Assoc 17:79-80

Olson JG, Ksiazek TG, Suhandiman, Triwibowo (1981) Zika virus, a cause of fever in Central Java, Indonesia. Trans Royal Soc Trop Med Hyg 75:389-391

Olson, JG, Ksiazek TG, Lee VH, Tan R, Shope RE (1985a) Isolation of Japanese encephalitis virus from Anopheles annularis and Anopheles vagus in Lombok, Indonesia. Trans Royal Soc Trop Med Hyg 79:845-847

Olson JG, Ksiazek TG, Tan R, Atmosoedjono S, Lee VH, Converse JD (1985b) Correlation of population indicies of female Culex tritaeniorhynchus with Japanese encephalitis viral activity in Kapuk, Indonesia. Southeast Asian J Trop Med Publ Hlth 16:337-342

Olson JG, Ksiazek TG, Gubler DJ, See R, Suharyono, Lubis I, Simanjuntak G, Lee V, Nalim S, Juslis J (1983) A survey for arboviral antibodies in sera of humans and animals in Lombok, Republic of Indonesia. Ann Trop Med Parasitol 77:131-137

Paul WS, Moore PS, Karabatsos N, Flood SP, Yamada S, Jackson T, Tsai T (1993) Outbreak of Japanese encephalitis on the island of Saipan, 1990. J Infect Dis 167:1053-1058

Peiris JSM, Amerasinghe FP, Amerasinghe PH, Ratnayake CB, Karunaratne SHPP, Tsai TF (1992) Japanese encephalitis in Sri Lanka - the study of an epidemic: vector incrimination, porcine infection and human disease. Trans R Soc Trop Med Hyg 86:307-313

Peiris JSM, Amerasinghe PH, Amerasinghe FP, Calisher CH, Perera LP, Arunagiri CK, Munasingha NB, Karunaratne SHPP (1994) Viruses isolated from mosquitoes collected in Sri Lanka. Am J Trop Med Hyg 51:154-161

Peiris JS, Amerasinghe FP, Arunagiri CK, Perera LP, Karunaratne SH, Ratnayake CB, Kulatilaka TA, Abeysinghe MR (1993) Japanese encephalitis in Sri Lanka: comparison of vector and virus ecology in different agro-climatic areas. Trans R Soc Trop Med Hyg 87:541-548

Platt GS, Way HJ, Bowen ET, Simpson DI, Hill MN, Kamath S, Bendell PJ, Heathcote OH (1975) Arbovirus infections in Sarawak, October 1968 - February 1970. Tembusu and Sindbis virus isolations from mosquitoes. Ann Trop Med Parasitol 69:65-71

Poidinger M, Hall RA, Mackenzie JS (1996) Molecular characterisation of the Japanese encephalitis serocomplex of flavivirus genus. Virology 218:417-421

Prasad SR, Kumar V, Marwaha RK, Batra KL, Rath RK, Pal SR (1993) An epidemic of encephalitis in Haryana: serological evidence of Japanese encephalitis in a few patients. Indian J Pediatr 30:905-910

Pyke AT, Williams DT, Nisbet DJ, van den Hurk AF, Taylor CT, Johansen CA, Macdonald J, Hall RA, Simmons RJ, Mason RJV, Lee JM, Ritchie SA, Smith GA, Mackenzie JS (2001) The appearance of a second genotype of Japanese encephalitis virus in the Australasian region. Am J Trop Med Hyg (in press) 
Reeves WC, Rudnick A (1951) A survey of the mosquitoes of Guam in two periods in 1948 and 1949 and its epidemiological implications. Am J Trop Med Hyg 31:633-658

Reynolds DR, Smith AD, Mukhopadhyay S, Chowdhury AK, De BK, Nath PS. Mondal SK, Das BK, Mukhopadhyay S (1996). Atmospheric transport of mosquitoes in northeast India. Med Vet Entomol 10:185-186

Ritchie SA, Rochester W (2001) Wind-blown mosquitoes and introduction of Japanese encephalitis into Australia. Emerg Infect Dis (in press)

Ritchie S, Haseler B, Foley P, Montgomery B (2001) Exotic mosquitoes in North Queensland: the true millennium bug? Arbovirus Res Australia 8:(in press)

Ritchie SA, Phillips D, Broom A, Mackenzie J, Poidinger M, van den Hurk A (1997) Isolation of Japanese encephalitis virus from Culex annulirostris in Australia. Am J Trop Med Hyg 56:80-84

Rosen L, Tesh RB, Lien JC, Cross JH (1978) Transovarial transmission of Japanese encephalitis virus by mosquitoes. Science 199:909-911

Russell RC (1995) Arboviruses and their vectors in Australia: an update on the ecology and epidemiology of some mosquito-borne arboviruses. Rev Med Vet Entomol 83:141-158

Russell RC, Dwyer DE (2000) Arboviruses associated with human disease in Australia. Microbes Infect 2:1693-1704

Scherer WF, Buescher EL, McClure HE (1959a) Ecological studies of Japanese encephalitis virus in Japan. V. Avian factors. Am J Trop Med Hyg 8:689-697

Scherer WF, Moyer JT, Izumi T (1959b) Immunologic studies of Japanese encephalitis virus in Japan. V. Maternal antibodies, antibody responses and viraemia following infection of swine. J Immunol 83:620-626

Shield J, Hanna J, Phillips D (1996) Reappearance of the Japanese encephalitis virus in the Torres Strait, 1996. Comm Dis Intell 20:191

Simpson DIH, Bowen ETW, Way HJ, Platt GS, Hill MN, Kamath S, Wah LT, Bendell PJE, Heathcote OHU (1974) Arbovirus infections in Sarawak, October 1968-February 1970: Japanese encephalitis virus isolations from mosquitoes. Ann Trop Med Parasitol 68:393-404

Soman RS, Rodrigues FM, Guttikar SN, Guru PY (1977) Experimental viraemia and transmission of Japanese encephalitis virus by mosquitoes and ardeid birds. Ind J Med Res 66:709-718

Spencer J, Broom AK, Buick T, Daniels PW, Doggett S, Hapgood G, Jarrett P, Lindsay MD, Lloyd G, Mackenzie JS, Merianos A, Moran R, Ritchie SA, Russell RC, Smith DW, Stenhouse F, Whelan P (2001) Murray Valley encephalitis virus surveillance and control initiatives in Australia: a report on behalf of the National Arbovirus Advisory Committee of the Communicable Diseases Network Australia. Commun Dis Intell 25:(in press)

Spicer PE (1997) Japanese encephalitis in Western Irian Jaya. J Travel Med 4:146-147

Spicer PE, Phillips D, Pike A, Johansen C, Melrose W, Hall RA (1999) Antibodies to Japanese encephalitis virus in human sera collected from Irian Jaya. Follow-up of a previously reported case of Japanese encephalitis in that region. Trans R Soc Trop Med Hyg 93:511-514

Spradbrow PB (1972) A survey for arbovirus antibodies in pigs and sheep in Queensland. Aust Vet J 48:402-407

Strahan R (1995) The Mammals of Australia, Second edition. New Holland Publishers Pty. Ltd., Melbourne, Australia

Stanley NF, Choo SB (1964) Studies of arboviruses in Western Australia. Bull WHO 30:221-226

Sulkin SE, Allen R (1974) Virus infections in bats. Monogr Virol 8:1-103

Takashima I, L (1989) Horizontal and vertical transmission of Japanese encephalitis virus by Aedes japonicus (Diptera: Culicidae). J Med Entomol 26:454-458

Tan R, Nalim S, Suwasono H, Jennings GB (1993) Japanese encephalitis virus isolated from seven species of mosquitoes collected at Semarang Regency, Central Java. Bul Penelit Kesehatan 21:1-5

Umenai T, Krzysko R, Bektimirov TA, Assaad FA (1985) Japanese encephalitis: current worldwide status. Bull WHO 63:625-631

van den Hurk AF, Johansen CA, Zborowski P, Phillips DA, Pyke AT, Mackenzie JS, Ritchie SA (2001a) Flaviviruses isolated from mosquitoes collected during the first recorded outbreak of Japanese encephalitis virus on Cape York Peninsula, Australia. Am J Trop Med Hyg 64:125-130

van den Hurk AF, Nisbet DJ, Johansen CA, Foley PN, Ritchie SA, Mackenzie JS (2001b) Japanese encephalitis on Badu Island, Australia: the first isolation of Japanese encephalitis virus from Culex gelidus in the Australasian region and the role of mosquito host-feeding patterns in virus transmission cycles. Trans R Soc Trop Med Hyg 95:595-600

Van Peenen PFD, Joseph PL, Atmososedjono S, Irsiana R, Saroso JS (1975a) Isolation of Japanese encephalitis virus from mosquitoes near Bogor, West Java, Indonesia. J Med Entomol 12:573-574 
Van Peenen PFD, Joseph PL, Atmosoedjonon S, Irsiana R, Saroso JS (1975b) Japanese encephalitis virus from pigs and mosquitoes in Jakarta, Indonesia. Trans Royal Soc Trop Med Hyg 69:477-479

Van Peenen PFD, Irsiana R, Saroso JS, Joseph SW, Shope RE, Joseph PL (1974a) First isolation of Japanese encephalitis virus from Java. Milit Med 139:821-823

Van Peenen PFD, Joseph SW, Atmosoedjono S, Irsiana R, Saroso JS, Saaroni O (1974b). Group B arbovirus antibodies in sentinel pigs near Jakarta. Indonesia. Southeast Asian J Trop Med Publ Health 5:1-3

Van Tongeren HAE, Wilterdink JB, Timmers WC (1960) Neutralising antibodies to the viruses of poliomyelitis, dengue types 1 and 2, Murray Valley and Japanese encephalitis in papuan populations of Netherlands New Guinea. Trop Geogr Med 12:208-215

Vaughn DW, Hoke CH (1992) The epidemiology of Japanese encephalitis: prospects for prevention. Epidemiol Rev 14:197-221

Vythilingam I, Oda K, Tsuchi H, Mahadevan S, Vijayamalar B (1994): Isolation of Japanese encephalitis virus from Culex sitiens mosquitoes in Selangor, Malaysia. J Am Mosq Control Assoc 10:228-229

Vythilingam I, Oda K, Chew TK, Mahadevan S, Vijayamalar B, Morita K, Tsuchie H, Igarashi A (1995) Isolation of Japanese encephalitis virus from mosquitoes collected in Sabak Bernam, Selangor, Malaysia in 1992. J Am Mosq Control Assoc 11:94-98

Vythilingam I, Oda K, Mahadevan S, Abdullah G, Thim CS, Hong CC, Vijayamalar B, Sinniah M, Igarashi A (1997) Abundance, parity, and Japanese encephalitis virus infection of mosquitoes (Diptera: Culicidae) in Sepang District, Malaysia. J Med Entomol 34:257-262

Whelan P, Hayes G, Carter J, Wilson A, Haigh B (2000) Detection of the exotic mosquito Culex gelidus in the Northern Territory. Comm Dis Intell 24:74-75

Widjaja S, Soekotjo W, Hartati S, Jennings GB, Corwin AL (1995) Prevalence of hemagglutinationinhibition and neutralizing antibodies to arboviruses in horses of Java. Southeast Asian J Trop Med Publ Health 26:109-113

Williams DT, Wang L-F, Daniels PW, Mackenzie JS (2000) Molecular characterisation of the first Australian isolate of Japanese encephalitis (JE) virus, the FU strain. J Gen Virol 81:2471-2480

Wisseman CL, Gajdusek DC, Schofield FD, Rosenzweig EC (1964) Arthropod-borne virus infections of aborigines indigenous to Australasia. Bull WHO 30:211-229

Wittesjo B, Eitrem R, Niklasson B, Vene S, Mangiafico JA (1995) Japanese encephalitis after a 10-day holiday in Bali. Lancet 345:856-857

Woodroofe GM, Marshall ID (1971) Arboviruses from the Sepik district of New Guinea. John Curtin School of Medical Research Annual Report, Australian National University, pp. 90-91

Wu C, Wu S (1957) Isolation of virus of B type encephalitis from Lasiohelea taiwana Shiraki bloodsucking midge. Acta Microbiologica Sinica 5:22-26

Wuryadi S, Soroso T (1989) Japanese encephalitis in Indonesia. Southeast Asian J Trop Med Publ Health 20:575-580

Yoshida M, Igarashi A, Suwendra P, Inada K, Maha MS, Kari K, Suda H, Antonio MT, Arhana BN, Takikawa Y, Maesawa S, Yoshida H, Chiba M (1999) The first report on human cases serologically diagnosed as Japanese encephalitis in Indonesia. Southeast Asian J Trop Med Public Health 30: 698-706 